\title{
Studies on Wheat (Triticum aestivum L.) Adaptability in The Province of West Sumatera, Indonesia
}

\author{
Irawati Chaniago, Irfan Suliansyah, Musliar Kasim, Reflinaldon \\ Department of Agroecotechnology, Faculty of Agriculture Andalas University, Padang, Indonesia \\ E-mail:irfan.suliansyah@yahoo.com
}

\begin{abstract}
Investigations were conducted at nine locations with elevation ranging from 570 to $1616 \mathrm{~m}$ above sea level in the Province of West Sumatera, Indonesia to evaluate the performance of some wheat genotypes originated from Slovak Republic. The experiments had been conducted from July to December 2011. The treatment consisted of 12 genotypes of Slovakian wheats (SO-1, SO-2, SO-3, SO-4, SO-5, SO-6, SO-7, SO-8, SO-9, SO-10, IS-Jarissa, and IS-1247) together with two wheat genotype of Indonesian origin (Nias and Dewata). The experimental units were arranged in a Completely Randomized Block Design with three replicates. Results indicated that most wheat genotypes exhibited similar characters examined while few others exhibited superior characters. Genotype Dewata had superior grain yield compared to the other genotypes. Some genotypes of Slovakian wheat (SO-3, SO-8, SO-9, dan SO-10) have good potentials in the following variables of time to heading, time to harvest, number of productive tillers, number of seeds per earing, seed weight per earing, and yield.
\end{abstract}

Keywords - Wheat, adaptability; Slovak Republic; West Sumatera

\section{INTRODUCTION}

Wheat (Triticum aestivum L.) is one of world major cereals crop belongs to the family of Poaceae and is not original to the tropical region. Wheat plants have been important for their source for carbohydrate and proteins. Wheat grains are the raw material for making various food products such as bread, noodles, biscuits, and other snacks. Azwar et al reported that wheat flour contains gluten that gives cohesiveness of the dough and will expand several times of its original volume when being baked [1].

Data from the Indonesian Central Bureau of Statistics (BPS) indicate that wheat flour has been a major source of carbohydrates, second to rice. Wheat flour contributes to carbohydrate sources as much as $14.26 \%$ while rice contributes the highest which is $79.62 \%$. Although rice contributes most of the carbohydrate consumption in Indonesia, the growth of rice contribution tended to decline $(-0.73 \%)$ for the last five years. On the other hand, the contribution of wheat flour to the carbohydrate source in Indonesia has increased for $12.5 \%$ annually. This situation resulted in increasing demand for wheat flour and very unfortunate for Indonesia who imports wheat for almost $100 \%$ of its need. This condition is worsened by the fact that Indonesia does not grow wheat widely. In the year 2012, Indonesia imported as much as 7.2 million tonnes of wheat grain [2]. An increasing demand for wheat flour every year will result in wheat import for 10 millions tonnes per year in the next ten years. This significant figure will make Indonesia the biggest wheat importing country in the world.

An annual increase in money spent for importing wheat should be reduced. Planting and developing wheat growth with appropriate technologies in accordance with agroclimatic condition in Indonesia is one of the efforts to reduce wheat import [3]. Indonesia has a huge amount of fertile land that can be used to grow wheat. However, wheat can grow well in Indonesia at an elevation higher than $800 \mathrm{~m}$ above the sea level. There are some municipalities in Indonesia that are suitable for growing wheat with total area of 1,972,000 hectares. Unfortunately, many parts of this area have been used for horticultural plants such as vegetables. The area lies in several islands including Sumatra, Kalimantan, Sulawesi, Nusa Tenggara, and Papua [4].

Wheat is not original to Indonesia; consequently, its genetic variability is very limited to this country. Some wheat varieties grown in Indonesia were previously introduced from other countries. Having passed several testing stages on adaptation and yield at different agroecosystems, wheat genotypes can then be released as new national wheat varieties. Therefore, continuous wheat breeding program should be carried out at different locations with different agroecological characteristics to find wheat genotypes adaptive to specific environment [5]. Every type 
of agroecosystem has specific constrain such as soil fertility, water insufficiency, low or high temperature, and pest and disease attack [6],[7]. An aptability test of a crop variety is usually carried out together with yield potential test at various locations (multi-location test).

Environmental variability affects crop productivity which in turn will force human being to grow a certain cultivar that is adaptive to specific environment. An environmental variability has been one of the key factors determining the growth performance and yield of plants. Multi-location adaptability test is one key point to obtain plant genotypes that can be further grown and developed widely. This test is generally used to evaluate the target plants in a widely distributed area where the plants to be grown [8],[9] states that multi-location test is aimed at studying the yield potential and adaptability of plant genotypes at different locations. Furthermore, the test is also designed to obtain high yield genotypes that are widely adaptive to various and/or specific location to increase wheat grain production in the area.

The research reported here is aimed at:

1. Carrying out wheat grow testing at various locations in the Province of West Sumatra.

2. Characterising wheat germpalsms for their morphological and agronomical traits.

\section{Methodology}

The experiments have been carried out from July to December 2011. Two Slovakia-origin wheat genotypes were grown in nine location of the Province of West Sumatra (Table 1). On the other hand, studying on the characterisation of wheat genotypes (Slovakia and Indonesian origin) were conducted at Sukarami, Aro Suka, Municupality of Solok.

TABLE I

VARIOUS Locations In The PROVINCE OF West SuMATRA THAT WERE USED TO GROW WHEAT

\begin{tabular}{|r|l|l|l|r|}
\hline \multirow{2}{*}{ No } & \multicolumn{3}{|c|}{ Locations } & Elevation \\
\cline { 2 - 5 } & \multicolumn{1}{|c|}{ Villages } & $\begin{array}{c}\text { Sub- } \\
\text { districts }\end{array}$ & $\begin{array}{c}\text { Municipal- } \\
\text { ities }\end{array}$ & asl) \\
\hline 1 & Pekonina & Sangir & Solok Selatan & 980 \\
\hline 2 & Golden & Sangir & Solok Selatan & 987 \\
\hline 3 & Sukarami & Aro Suka & Solok & 1048 \\
\hline 4 & Alahan Panjang & L. Gumanti & Solok & 1616 \\
\hline 5 & Koto Ilalang & Balingka & Agam & 1200 \\
\hline 6 & Balingka & Balingka & Agam & 1040 \\
\hline 7 & Rambatan & Rambatan & Tanah Datar & 570 \\
\hline 8 & Sumanik & Salimpaung & Tanah Datar & 800 \\
\hline 9 & Tabek Patah & Tabek Patah & Tanah Datar & 1000 \\
\hline
\end{tabular}

Two wheat genotypes original to Slovak (IS-Jarissa and IS-1247) were used to study the wheat growth and adaptability at different agroclimatic conditions. Meanwhile, for the study of wheat characteristics we planted 12 genotypes of wheat originated from Slovak Republic i.e. IS Jarissa, IS-1247, SO-1, SO-2, SO-3, SO-4, SO-5, SO-6, SO7, SO-8, SO-9, dan SO-10 and two genotypes of wheat of Indonesia as follow Nias and Dewata.

The experimental unit was $5 \times 1.75 \mathrm{~m}$ in size and each treatment was replicated three times. Two seeds were directly planted in each planting spot and three weeks later (3 WAP) one plant was left for the experimental purposes. The insecticide ${ }^{\circledR}$ Furadan (active ingredient of Carbofuran) was applied to the soil at the time of planting. Fertilizers of $150 \mathrm{~kg} / \mathrm{ha}$ urea, $100 \mathrm{~kg} / \mathrm{ha} \mathrm{SP} 36$, and $100 \mathrm{~kg} / \mathrm{ha} \mathrm{KCl}$ were applied. A half dose of urea together with a full dose of SP 36 and $\mathrm{KCl}$ were applied at $1 \mathrm{WAP}$ and the rest of urea was applied at 5 WAP. Weed control was conducted at 3 and 6 WAP. Pest and disease control was applied when needed.

The following observations were carried out for data collection:

(1) Time to flowering was recorded when $50 \%$ or more of the plants has flowered. (2) Time to harvest was recorded when at least $75 \%$ of the panicle has turned yellow and the grain has hardened. (3) Plant height, was measured from the base of the stalk to the tip of panicle without measuring the length of the awn. (4) The number of productive tillers was counted at the time of harvest. Productive tiller is a tiller that produced panicle and grains. (5) The number of seeds per spikelet. (6) The number of grains per panicle. (7) Seed weight per clump, seeds were detached from the panicle and dried to approximately $14 \%$ of water content. (8) Some other morphological characters including stem, leaf, flower, and panicle.

\section{RESULT}

\section{A. Studies on Growing Wheat at Various Agroclimates at the Province of West Sumatra}

Wheat germination (50\% of seedlings have emerged from the soil surface) happened one week after planting. Generally, the wheat grew well and relatively homogenous. The wheat that was planted at various elevations demonstrated relatively good vegetative growth responses (Figure 1 shows plant growth at Alahan Panjang, $1616 \mathrm{~m}$ above sea level). We also found that the wheat plants at 8 WAP grew well and having no significant symptoms of pest and disease's attack except for ones grew at Pekonina (Solok Selatan) and Alahan Panjang (Solok). We found a species of soil insect, Agrotis ipsilon, at these two locations at the early stages of the wheat growth resulted in the death of several plants. The insect ate the base of the stem under the soil surface (Figure 2).

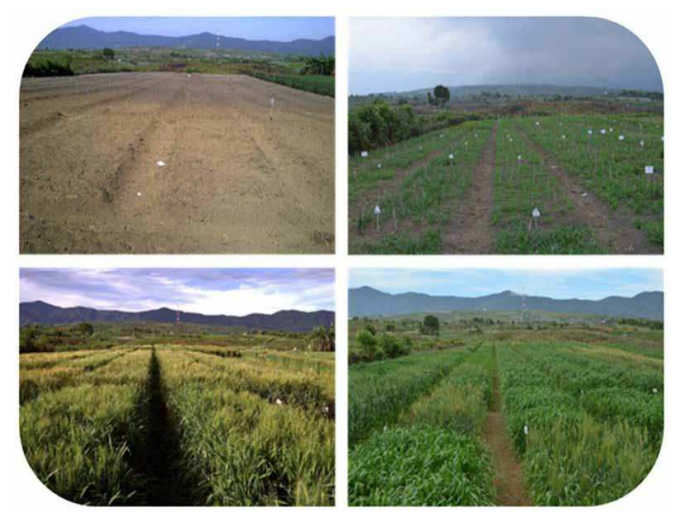

Fig. 1. Wheat growth at Alahan Panjang - Municipality of Solok 


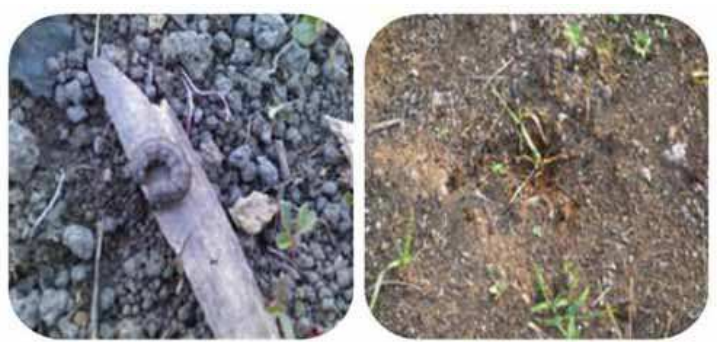

Fig. 2. Photo of insect of Agrotis ipsilon (left) and wheat plant that was attacked by the insect (right)

Two wheat genotypes (IS-Jarissa dan IS-1247) grown at nine locations did not show significant difference in growth response. Wheat cv. IS-Jarissa grew higher than that of IS1247 at almost all locations. Data of plant height at $4-10$ WAP can be seen at Table 2 .

Quantitative data on the growth of wheat at nine locations are presented at Table 3 . Wheat cv. IS-Jarissa consistently flowered earlier than that of IS-1247 in all locations. The time to flowering of IS-Jarissa and IS-1247 were 11-13 WAP and 12-16 WAP, respectively. These figures are in accordance with the time to harvesting. Wheat cv. IS-Jarissa was harvested at 18-19 WAP whereas cv. IS-1247 was harvested at 20-22WAP.

Wheat cv. IS-Jarissa that was grown at an elevation of $800 \mathrm{~m}$ above the sea level demonstrated taller plants than that of IS-1247. In contrast, when grown at elevation lower than $800 \mathrm{~m}$ above sea level, cv. IS-1247 grew taller than that of cv. IS-Jarissa. The number of productive tillers varied within all nine locations for the two wheat cultivars. It is interesting to note that the higher the elevation the higher the wheat yield components (number of seeds/spikelet, number of seeds/panicle, and number of seeds/clump) observed. The highest yield was recorded from the wheat grown at Alahan Panjang - Municipality of Solok (1616 m above sea level).

TABLE II

Plant HeIGHT Of Two WhEAT GENOTYPES GRown At VARIOUS LOCATIONS AT THE PROvince OF WeSt Sumatra

\begin{tabular}{|l|c|c|c|c|c|c|c|c|}
\hline \multirow{2}{*}{ Genotypes } & \multicolumn{7}{|c|}{ Plant Height (cm) - WAP } \\
\cline { 2 - 8 } & $\mathbf{4}$ & $\mathbf{5}$ & $\mathbf{6}$ & $\mathbf{7}$ & $\mathbf{8}$ & $\mathbf{9}$ & $\mathbf{1 0}$ \\
\hline IS-1247 & 28.6 & 32.7 & 37.9 & 42.9 & 48.2 & 52.3 & 56.8 \\
\hline IS-Jarissa & 30.2 & 34.9 & 36.9 & 41.8 & 46.7 & 55.5 & 66.7 \\
\hline \multicolumn{7}{|c|}{ Golden - Solok Selatan } \\
\hline IS-1247 & 27.5 & 32.1 & 37.4 & 43.3 & 49.6 & 54.0 & 59.0 \\
\hline IS-Jarissa & 29.8 & 34.3 & 37.9 & 45.1 & 52.7 & 63.6 & 73.5 \\
\hline \multicolumn{7}{|c|}{ Sukarami - Solok } \\
\hline IS-1247 & 17.5 & 23.8 & 28.5 & 31.4 & 34.0 & 39.1 & 42.2 \\
\hline IS-Jarissa & 18.8 & 24.2 & 29.5 & 31.1 & 33.6 & 38.2 & 40.7 \\
\hline \multicolumn{7}{|c|}{ Alahan Panjang - Solok } \\
\hline IS-1247 & 12.2 & 17.5 & 22.0 & 28.4 & 35.0 & 43.8 & 52.1 \\
\hline IS-Jarissa & 16.9 & 21.9 & 28.5 & 37.3 & 44.6 & 54.4 & 64.7 \\
\hline & 14.2 & 22.0 & 30.0 & 38.5 & 45.6 & 52.8 & 60.5 \\
\hline IS-1247 & \multicolumn{7}{|c|}{ Koto Ilalang - Agam } \\
\hline
\end{tabular}

\begin{tabular}{|l|c|c|c|c|c|c|c|}
\hline \multirow{2}{*}{ Genotypes } & \multicolumn{7}{|c|}{ Plant Height (cm) - WAP } \\
\cline { 2 - 8 } & $\mathbf{4}$ & $\mathbf{5}$ & $\mathbf{6}$ & $\mathbf{7}$ & $\mathbf{8}$ & $\mathbf{9}$ & $\mathbf{1 0}$ \\
\hline IS-Jarissa & 14.3 & 22.1 & 30.6 & 39.3 & 46.7 & 54.1 & 62.0 \\
\hline \multicolumn{7}{|c|}{ Balingka - Agam } \\
\hline IS-1247 & 14.2 & 21.8 & 29.2 & 37.2 & 43.8 & 51.3 & 59.3 \\
\hline IS-Jarissa & 14.5 & 21.9 & 30.2 & 39.3 & 46.4 & 54.0 & 62.2 \\
\hline \multicolumn{7}{|c|}{ Rambatan - Tanah Datar } \\
\hline IS-1247 & 19.0 & 28.5 & 27.2 & 27.4 & 29.4 & 31.3 & 64.5 \\
\hline IS-Jarissa & 20.3 & 29.6 & 32.4 & 34.2 & 39.8 & 46.1 & 68.0 \\
\hline \multicolumn{7}{|c|}{ Sumanik - Tanah Datar } \\
\hline IS-1247 & 19.77 & 23.07 & 27.90 & 28.57 & 31.61 & 34.65 & 62.91 \\
\hline IS-Jarissa & 18.62 & 28.87 & 32.41 & 33.28 & 38.47 & 43.67 & 67.55 \\
\hline \multicolumn{7}{|c|}{ Tabek Patah - Tanah Datar } \\
\hline IS-1247 & 20.9 & 23.1 & 28.0 & 28.7 & 33.3 & 37.8 & 64.9 \\
\hline IS-Jarissa & 19.1 & 29.6 & 33.8 & 34.5 & 39.8 & 45.0 & 72.7 \\
\hline
\end{tabular}

TABLE III

DATA OF WHEAT CV. IS-JARISSA AND Is-1247 GROWN AT NINE

\begin{tabular}{|c|c|c|c|c|c|c|c|}
\hline \\
\hline Genotype & $\begin{array}{c}\text { Time } \\
\text { to } \\
\text { head- } \\
\text { ing }\end{array}$ & $\begin{array}{c}\text { Time } \\
\text { to } \\
\text { Harves } \\
\text {-ting }\end{array}$ & $\begin{array}{c}\text { Plant } \\
\text { Height } \\
(\mathrm{cm})\end{array}$ & $\begin{array}{c}\text { Number } \\
\text { of } \\
\text { Tillers }\end{array}$ & $\begin{array}{c}\text { Number } \\
\text { of } \\
\text { Seeds/ } \\
\text { Spikelet }\end{array}$ & \begin{tabular}{|c} 
Number \\
of \\
Seeds/ \\
Panicle \\
\end{tabular} & $\begin{array}{c}\text { Seed } \\
\text { Weigh } \\
\text { t/ } \\
\text { Clump } \\
\text { (g) }\end{array}$ \\
\hline \multicolumn{8}{|c|}{ Pekonina - Sangir, Solok Selatan } \\
\hline IS-Jarissa & 12 & 19 & 79.3 & 11.2 & 1.7 & 27.3 & 3.9 \\
\hline IS-1247 & 14 & 21 & 66.3 & 10.7 & 1.5 & 23.2 & 3.3 \\
\hline \multicolumn{8}{|c|}{ Golden - Solok Selatan } \\
\hline IS-Jarissa & 12 & 19 & 66.7 & 11.2 & 2.1 & 31.2 & 4.4 \\
\hline IS-1247 & 14 & 21 & 57.7 & 11.0 & 1.5 & 26.1 & 3.5 \\
\hline \multicolumn{8}{|c|}{ Sukarami - Solok *) } \\
\hline IS-Jarissa & 11 & 19 & 84.9 & 13.0 & 0.5 & 3.6 & 0.5 \\
\hline IS-1247 & 14 & 22 & 51.4 & 17.0 & 0.8 & 3.1 & 0.5 \\
\hline \multicolumn{8}{|c|}{ Alahan Panjang - Solok } \\
\hline IS-Jarissa & 13 & 19 & 80.5 & 19.0 & 3.4 & 46.3 & 23.1 \\
\hline IS-1247 & 16 & 21 & 80.3 & 20.3 & 2.6 & 46.8 & 20.3 \\
\hline \multicolumn{8}{|c|}{ Koto Ilalang - Agam } \\
\hline IS-Jarissa & 12 & 19 & 113.6 & 21.0 & 1.7 & 23.7 & 13.5 \\
\hline IS-1247 & 14 & 21 & 106.3 & 19.9 & 1.4 & 18.1 & 6.4 \\
\hline \multicolumn{8}{|c|}{ Balingka - Agam } \\
\hline IS-Jarissa & 12 & 19 & 84.8 & 22.9 & 1.3 & 19.9 & 4.9 \\
\hline IS-1247 & 14 & 21 & 96.2 & 18.0 & 1.3 & 18.3 & 1.9 \\
\hline \multicolumn{8}{|c|}{ Rambatan - Tanah Datar } \\
\hline IS-Jarissa & 12 & 18 & 28.5 & 25.0 & 1.4 & 12.9 & 5.3 \\
\hline IS-1247 & 15 & 24 & 22.7 & 16.6 & 0.8 & 12.7 & 1.3 \\
\hline \multicolumn{8}{|c|}{ Sumanik - Tanah Datar } \\
\hline IS-Jarissa & 11 & 18 & 52.3 & 12.0 & 1.4 & 17 & 2.5 \\
\hline IS-1247 & 12 & 20 & 89.4 & 33.0 & 0.7 & 17 & 2.4 \\
\hline \multicolumn{8}{|c|}{ Tabek Patah - Tanah Datar **) } \\
\hline IS-Jarissa & 12 & 19 & 80.2 & 59.1 & 0.9 & 11.4 & 0.4 \\
\hline IS-1247 & 14 & 21 & 70.5 & 51.5 & & & \\
\hline
\end{tabular}

*) Plants were attacked by disease

**) Plants were attacked by rat and scab disease 


\section{B. Morphological Characters of Several Genotypes of Wheat of Slovakian Origin}

Agronomical and morphological characters on various wheat genotypes varied between genotypes tested (Table 4). The following observation, however, did not show significant differences i.e. the colour of stem nodes, stem surface, leaf tips, leaf nerves, leaf surface, seed colour, and seed shape. However, we found variations in the colour of the basal of the stem which was green for genotype SO-9 but yellowish green for other genotypes. We also found that all genotypes except for SO-4 had awn at the tip of the spikelet (Figure 3). This genotype (SO-4) was the only cultivar that did not produce seeds throughout the experiment.
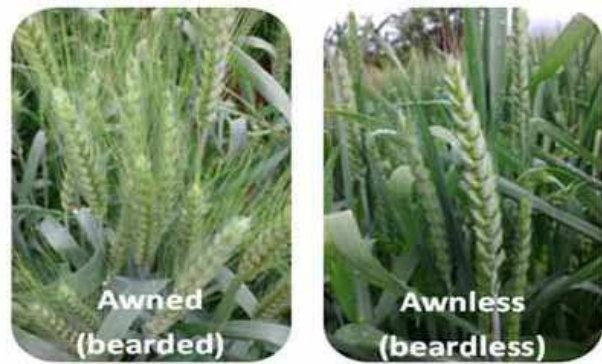

Fig. 3. Wheat plants having awn at the spikelet (left) and awnless spikelet (right)

Wheat genotype of SO-10 demonstrated the highest number in plant height with an average of $85.70 \mathrm{~cm}$ followed by Dewata with plant height of $85.10 \mathrm{~cm}$. On the other hand, genotypes of Nias and SO-7 were shown to be the lowest in plant height of 66.40 and $66.50 \mathrm{~cm}$, respectively. The other genotypes showed plant height ranging from 69.50 to $82.70 \mathrm{~cm}$.

Two wheat genotypes of Indonesia (Nias and Dewata) and some Slovakian origin demonstrated a shorter vegetative growth period compared to some other Slovakian origin wheat tested. This resulted in earlier time to enter the generative stage of growth. Data on Table 4 indicates variations in time to heading and time to harvesting within the wheat genotypes. The earliest time to heading was 10 WAP and recorded from the genotypes of SO-3, SO-8, SO-9, SO-10, Dewata, dan Nias. In contrast, the longest time to heading was found to be 16 MST for the genotypes of IS1247. Overall, time to harvesting varied from 17 to $21 \mathrm{WAP}$, and the genotypes of IS-1247 was harvested the latest.

The highest amount of productive tillers was found from the genotype SO-10 which was 30 tillers per clump, followed by Dewata of 29.50 tillers per clump. The lowest amount of productive tillers (10.63 tillers) was found from the group of genotype SO-4, and Nias producing 16.00 tillers per clump. Other wheat genotypes produced tillers ranging from 19.00 to 26.00 .

The highest amount of seeds/spikelet was found from the genotype of SO-5 followed by IS-Jarissa as much as 3.67 and 3.35 seeds per spikelet, respectively. On the other hand, the lowest amount of seeds/spikelet was recorded from the group of SO-1 followed by SO-2 which were 2.45 and 3.32 seeds/spikelet, respectively. Other wheat genotypes tested produced the amount of seeds per spikelet ranging from 2.56 to 3.23. In addition, wheat genotypes SO-3 and Nias produced the highest amount of seeds per panicle $(57.00$ seeds), whereas the lowest amount of seeds was found in the genotype SO-2 (42.50 seeds). Other wheat genotypes produced $44.50-56.50$ seeds per panicle.

The highest amount of seed weight per panicle was found from the group of genotype S0-3 followed by genotype Dewata with the weight of 2.39 and $2.38 \mathrm{~g}$, respectively. A similar trend was found for the highest amount of seed weight per clump. Genotype Dewata had $75.60 \mathrm{~g}$ followed by SO-3 with seeds weight of 52.70 per clump. However, the lightest seeds weight was from the group of SO-1 and followed by IS-1247 genotypes with the seed weight of 1.05 and $1.11 \mathrm{~g}$, respectively. Other wheat genotypes produced seed weight per panicle ranging from 1.13 to $2.35 \mathrm{~g}$. The genotypes of SO-1 and IS-1247 produced the lowest seed weight per clump of 19.90 and $20.30 \mathrm{~g}$, respectively. Other wheat genotypes demonstrated seed weight per clump ranging from 23.10 to $50.20 \mathrm{~g}$. Indonesian wheat genotype of Dewata had the highest number of 1000 seed weight of 44.10 gram followed by Slovakian SO-9 of 43.70 gram. The lowest number of 1000 seed weight was found from the group of SO-1 followed by IS-1247 with the seed weight of 23.96 and $24.26 \mathrm{~g}$ per 1000 weight, respectively. Other wheat genotypes produced 1000 seeds weight ranging from 25.79 to 41.98 gram.

Having evaluated data on various wheat genotypes at Alahan Panjang in the Province of West Sumatra, we found differences within the genotypes tested. The difference was observed for the growth and yield components. This difference is resulted from the genetic composition of each wheat genotypes and their potential to adapt to the climatic and soil conditions at the place of the experiment (Miko et al., 2006). However, it is interesting to note that some genotypes demonstrated relatively similar characters to one another. Generally, genotype Dewata had the best performance as demonstrated through its growth and yield components that were better than those of other genotypes. Dewata was originally from India and was previously named as DWR 162. In the year 2002, this wheat cultivar was officially released to be Indonesian wheat cultivar. This is one of the reasons why cultivar Dewata grew better throughout the experiment as it has adapted to the Indonesian climates and soil [4].

TABLE IV

Agronomical AND Morphological CHaracters OF SOME WHEAT GENOTYPES OF SLOVAKIAN AND INDONESIAN ORIGIN, GROWN AT ALAHAN PANJANG, WEST SUMATRA

\begin{tabular}{|c|c|c|c|c|c|c|c|}
\hline $\begin{array}{c}\text { Growth } \\
\text { Response }\end{array}$ & $\begin{array}{c}\text { IS- } \\
\text { Jariss } \\
\text { a }\end{array}$ & $\begin{array}{c}\text { IS- } \\
1247\end{array}$ & SO-1 & $\mathrm{SO}-2$ & $\mathrm{SO}-3$ & $\mathrm{SO} 4$ & $\mathrm{SO}-5$ \\
\hline $\begin{array}{l}\text { Color of } \\
\text { stem node }\end{array}$ & Yellow & Yellow & Yellow & Yellow & Yellow & Yellow & Yellow \\
\hline $\begin{array}{l}\text { Color of } \\
\text { Stem base }\end{array}$ & $\begin{array}{l}\text { Yellowis } \\
\text { Green }\end{array}$ & $\begin{array}{l}\text { Yellowis } \\
\text { Green }\end{array}$ & $\begin{array}{l}\text { Yellowis } \\
\text { Green }\end{array}$ & $\begin{array}{l}\text { Yellowis } \\
\text { Green }\end{array}$ & $\begin{array}{l}\text { Yellowis } \\
\text { Green }\end{array}$ & $\begin{array}{l}\text { Yellowis } \\
\text { Green }\end{array}$ & $\begin{array}{l}\text { Yellowish } \\
\text { Green }\end{array}$ \\
\hline $\begin{array}{l}\text { Stem } \\
\text { Surface }\end{array}$ & Smooth & Smooth & Smooth & Smooth & Smooth & Smooth & Smooth \\
\hline Leaf tip & Pointed & Pointed & Pointed & Pointed & Pointed & Pointed & Pointed \\
\hline Leaf Nerve & Paralel & Paralel & Paralel & Paralel & Paralel & Paralel & Paralel \\
\hline $\begin{array}{l}\text { Leaf } \\
\text { Surface }\end{array}$ & Hairy & Hairy & Hairy & Hairy & Hairy & Hairy & Hairy \\
\hline Seed Color & Brown & Brown & Brown & Brown & Brown & - & Brown \\
\hline Seed Shape & Oval & Oval & Oval & Oval & Oval & - & Oval \\
\hline
\end{tabular}




\begin{tabular}{|c|c|c|c|c|c|c|c|}
\hline $\begin{array}{l}\text { Awn } \\
\text { Number of } \\
\text { Leaf }\end{array}$ & $\begin{array}{l}\text { Yes } \\
57.00\end{array}$ & $\begin{array}{l}\text { Yes } \\
60.75\end{array}$ & $\begin{array}{l}\text { Yes } \\
63.75\end{array}$ & $\begin{array}{l}\text { Yes } \\
75.00\end{array}$ & $\begin{array}{l}\text { Yes } \\
50.25\end{array}$ & \begin{tabular}{|l} 
No \\
63.75
\end{tabular} & $\begin{array}{l}\text { Yes } \\
\quad 61.50\end{array}$ \\
\hline $\begin{array}{l}\text { Internode } \\
\text { Amount }\end{array}$ & 4.00 & 4.00 & 4.00 & 4.00 & 4.00 & 4.00 & 4.00 \\
\hline $\begin{array}{l}\text { Longest } \\
\text { Leaf }(\mathrm{cm})\end{array}$ & 27.15 & 26.83 & 26.90 & 26.98 & 28.43 & 26.68 & 26.20 \\
\hline $\begin{array}{l}\text { Widest Leaf } \\
(\mathrm{cm})\end{array}$ & 1.30 & 1.28 & 1.85 & 1.25 & 1.60 & 1.28 & 1.50 \\
\hline $\begin{array}{l}\text { Panicle } \\
\text { Length } \\
(\mathrm{cm})\end{array}$ & 10.78 & 10.13 & 11.35 & 10.13 & 10.75 & 10.00 & 10.63 \\
\hline $\begin{array}{l}\text { Plant height } \\
(\mathrm{cm}) 11 \\
\text { WAP }\end{array}$ & 80.50 & 80.30 & 77.60 & 69.50 & 81.20 & 76.40 & 76.20 \\
\hline $\begin{array}{l}\text { Time to } \\
\text { Flowering } \\
\text { (WAP) }\end{array}$ & 13.00 & 16.00 & 14.00 & 14.00 & 10.00 & 14.00 & 14.00 \\
\hline $\begin{array}{l}\text { Time to } \\
\text { Harvesting } \\
\text { (WAP) }\end{array}$ & 19.00 & 21.00 & 20.00 & 20.00 & 17.00 & 19.00 & 19.00 \\
\hline $\begin{array}{l}\text { Number of } \\
\text { Productive } \\
\text { Tiller }\end{array}$ & 19.00 & 20.25 & 21.25 & 25.00 & 20.75 & 21.25 & 20.50 \\
\hline $\begin{array}{l}\text { Seed } \\
\text { Length }\end{array}$ & 0.55 & 0.58 & 0.58 & 0.60 & 0.63 & - & 0.58 \\
\hline $\begin{array}{l}\text { Amount of } \\
\text { seeds/ } \\
\text { spikelet }\end{array}$ & 3.35 & 2.56 & 2.38 & 2.45 & 3.05 & - & 3.67 \\
\hline $\begin{array}{l}\text { Amount of } \\
\text { seeds/ } \\
\text { panicle }\end{array}$ & 46.25 & 46.75 & 44.00 & 42.50 & 57.00 & - & 44.50 \\
\hline $\begin{array}{l}\text { Seed } \\
\text { weight } \\
\text { /panicle (g) }\end{array}$ & 1.32 & 1.11 & 1.05 & 1.13 & 2.39 & - & 1.31 \\
\hline $\begin{array}{l}\text { Seed } \\
\text { weight/ } \\
\text { clump }(\mathrm{g})\end{array}$ & 23.10 & 20.30 & 19.90 & 25.40 & 52.70 & - & 24.80 \\
\hline $\begin{array}{l}\text { Weight of } \\
1000 \text { seeds } \\
\text { (g) }\end{array}$ & 28.89 & 24.26 & 23.96 & 25.79 & 41.98 & - & 29.81 \\
\hline $\begin{array}{l}\text { Color of } \\
\text { stem node }\end{array}$ & Yellow & Yellow & Yellow & Yellow & Yellow & Yellow & Yellow \\
\hline $\begin{array}{l}\text { Color of } \\
\text { Stem base }\end{array}$ & $\begin{array}{l}\text { Yellowi } \\
\text { sh } \\
\text { Green }\end{array}$ & $\begin{array}{l}\text { Yellowi } \\
\text { sh } \\
\text { Green }\end{array}$ & $\begin{array}{l}\text { Yellowi } \\
\text { sh } \\
\text { Green }\end{array}$ & Green & \begin{tabular}{|l|} 
Yellowi \\
sh \\
Green
\end{tabular} & $\begin{array}{l}\text { Yellowi } \\
\text { sh } \\
\text { Green }\end{array}$ & $\begin{array}{l}\text { Yellowis } \\
\text { h Green }\end{array}$ \\
\hline $\begin{array}{l}\text { Stem } \\
\text { Surface }\end{array}$ & Smooth & Smooth & Smooth & Smooth & Smooth & Smooth & Smooth \\
\hline Leaf tip & Pointed & Pointed & Pointed & Pointed & Pointed & Pointed & Pointed \\
\hline Leaf Nerve & Paralel & Paralel & Paralel & Paralel & Paralel & Paralel & Paralel \\
\hline $\begin{array}{l}\text { Leaf } \\
\text { Surface }\end{array}$ & Hairy & Hairy & Hairy & Hairy & Hairy & Hairy & Hairy \\
\hline Seed Color & Brown & Brown & Brown & Brown & Brown & Brown & Brown \\
\hline Seed Shape & Oval & Oval & Oval & Oval & Oval & Oval & Oval \\
\hline Awn & Yes & Yes & Yes & Yes & Yes & Yes & Yes \\
\hline $\begin{array}{l}\text { Number of } \\
\text { Leaf }\end{array}$ & 72.00 & 61.50 & 66.00 & 78.00 & 90.00 & 83.50 & 48.00 \\
\hline $\begin{array}{l}\text { Internode } \\
\text { Amount }\end{array}$ & 4.00 & 4.00 & 4.00 & 4.00 & 5.00 & 4.00 & 4.00 \\
\hline $\begin{array}{l}\text { Longest } \\
\text { Leaf }(\mathrm{cm})\end{array}$ & 25.85 & 26.65 & 26.05 & 30.13 & 29.98 & 26.13 & 24.00 \\
\hline $\begin{array}{l}\text { Widest Leaf } \\
(\mathrm{cm})\end{array}$ & 1.23 & 1.48 & 1.10 & 1.28 & 1.60 & 1.68 & 1.28 \\
\hline $\begin{array}{l}\text { Panicle } \\
\text { Length } \\
(\mathrm{cm})\end{array}$ & 10.70 & 11.00 & 8.63 & 10.45 & 11.05 & 9.78 & 10.25 \\
\hline $\begin{array}{l}\text { Plant height } \\
(\mathrm{cm}) 11 \\
\text { WAP }\end{array}$ & 71.30 & 66.50 & 79.90 & 82.70 & 85.70 & 85.10 & 66.40 \\
\hline
\end{tabular}

\begin{tabular}{|l|c|c|c|c|c|c|c|}
\hline $\begin{array}{l}\text { Time to } \\
\text { Flowering } \\
\text { (WAP) }\end{array}$ & 14.00 & 14.00 & 10.00 & 10.00 & 10.00 & 10.00 & 10.00 \\
\hline $\begin{array}{l}\text { Time to } \\
\text { Harvesting } \\
\text { (WAP) }\end{array}$ & 20.00 & 20.00 & 17.00 & 17.00 & 17.00 & 17.00 & 17.00 \\
\hline $\begin{array}{l}\text { Number of } \\
\text { Productive } \\
\text { Tillering }\end{array}$ & 24.00 & 20.50 & 22.00 & 26.00 & 30.00 & 29.50 & 16.00 \\
\hline $\begin{array}{l}\text { Seed } \\
\text { Length }\end{array}$ & 0.55 & 0.55 & 0.63 & 0.65 & 0.55 & 0.60 & 0.65 \\
\hline $\begin{array}{l}\text { Amount of } \\
\text { seeds/ } \\
\text { spikelet }\end{array}$ & 2.86 & 3.23 & 2.59 & 2.67 & 2.90 & 3.11 & 3.05 \\
\hline $\begin{array}{l}\text { Amount of } \\
\text { seeds/ } \\
\text { panicle }\end{array}$ & 49.50 & 48.25 & 54.00 & 54.75 & 56.50 & 54.50 & 57.00 \\
\hline $\begin{array}{l}\text { Seed } \\
\text { weight } \\
\text { /panicle (g) }\end{array}$ & 1.49 & 1.43 & 1.98 & 2.35 & 2.22 & 2.38 & 2.12 \\
\hline $\begin{array}{l}\text { Seed } \\
\text { weight/ } \\
\text { clump (g) }\end{array}$ & 34.20 & 28.60 & 46.10 & 47.50 & 50.20 & 75.60 & 47.00 \\
\hline $\begin{array}{l}\text { Weight of } \\
1000 \text { seeds } \\
\text { (g) }\end{array}$ & 30.42 & 29.89 & 36.77 & 43.70 & 39.77 & 44.10 & 37.34 \\
\hline
\end{tabular}

There are four wheat genotypes of Slovakian origin, SO-3, SO-8, SO-9, and SO-10, demonstrated good growth performance in our experiment. The genotypes flowered earlier and consequently can be harvested earlier. In addition, they have number of seeds and seed weight that were relatively similar to those of cultivar Dewata that was used as the control treatment.

\section{Pest and Disease Found at the Experiment}

During the experiment we found some plants that were subjected to pest and disease at various stages of wheat growth. Unfortunately, these were observed at all experimental sites. The most annoying pest that affected wheat at the early growth stage was Agrotis ipsilon and orong-orong that caused the death of the wheat seedling through eating of the base of the seedling. Caterpillar and Coccinellidae were found at the vegetative stage of the wheat growth. We also found that the wheat plants were suffering from the scab disease (Figure 4).

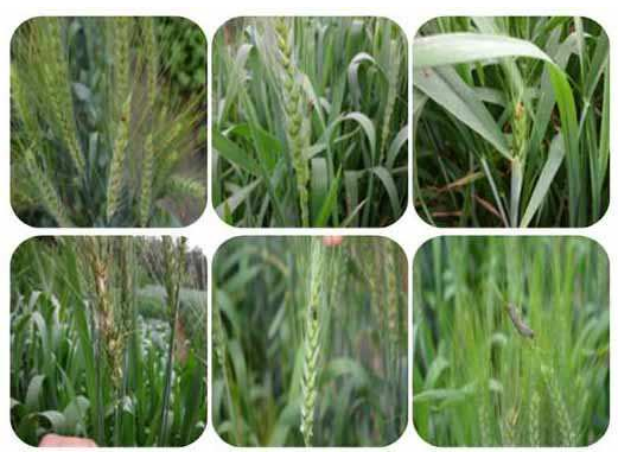

Fig. 4. Pest and disease found at the experimental sites at the Province of West Sumatra 


\section{CONCLUSIONS}

Based on the experiments and data collected from various locations, the following conclusions can be drawn: Alahan Panjang is the best location to grow wheat as indicated by the best growth and highest yield. Reducing the elevation of the place resulted in significant reduction in yield. There is no difference in the morphological characters between Slovakian wheat to Indonesian wheat tested. Agronomical analysis resulted in four Slovakian wheat genotypes with high yield potential. The genotypes are SO-3, SO-8, SO-9, dan SO-10 and have been chosen to be the candidates for further experiments. The following insects were found to be attacking the wheats: Agrotis ipsilon, caterpillar, orong-orong, and Coccinillidae. Some disease found were leaf black spot, scab, and leaf blight.

\section{ACKNOWLEDGMENT}

This study is part of the National Strategic Competitive Research Program. We would like to thank the Directorate General of Higher Education, Ministry of National Education for granting us the research fund. We are also very grateful to OSIVO a.s. of Slovak Republic for providing us with some wheat genotypes. To other parties who directly or indirectly assist in the implementation of these activities is also acknowledged.

\section{REFERENCES}

[1] Azwar, R., T. Danakusuma, dan A.A. Daradjat. 1988. Prospek pengembangan terigu di Indonesia. Buku 1. Risalah Simposium Tanaman Pangan II. Puslitbangtan. Bogor,12-13 Maret 1988. 17 hlm.

[2] Detikfinance. 2012. Republik Indonesia Pengimpor Gandum Terbesar Kedua di Dunia. http://finance.detik.com/read/2012/ 06/12/ 103707/1938780/1036/ri-pengimpor-gandum-terbesar-kedua-didunia

[3] Sovan, M. 2002. Penangan pascapanen gandum. Disampaikan pada acara rapat koordinasi pengembangan gandum di Pasuruan, Jawa Timur, 3-5 September 2002. Direktorat Serealia Direktorat Jenderal Bina Produksi Tanaman Pangan.

[4] Sinar Tani. 2006. Prospek Gandum Menggiurkan. http://pustaka. litbang.deptan.go.id/inovasi/k1060613.pdf. 9 February 2012.

[5] Allard, R.W. \& A.D. Bradshow. 1964. Implication genotype environment interaction in appliedplant breeding. CropSci.4:503-507.

[6] Simanullang, Z.A., T. Tjubarat, dan E. Suamadi. 1995. Pemaduan beberapa sifat baik IR64 dan IR19961. Prosiding Seminar Apresiasi Hasil Penelitian Padi Balitpa Sukamandi.

[7] Suhartini, T., I. Hanarida, Sutrisno, S. Rianawati, Sustiprijatno, dan Kurniawan. 1997. Pewarisan sifat toleran keracunan besi pada beberapa varietas padi. Penelitian Pertanian 16(1):26-32.

[8] Berger, J.D., J. Speijers, R.L. Sapra and U.C. Sood. 2007. Genotype by environment interaction and chickpea improvement. In: Chickpea Breeding and Management. Eds. S.S. Yadav, R.J. Redden, W. Chen and B. Sharma. CAB International, pp. 617-629.

[9] Soewito, T. 2003. Stabilitas Hasil Beberapa Genotipe Padi Sawah Umur Genjah. Penelitian Pertanian. 6 (2): 77-80.

[10] Miko S., A. M. Falaki, I. U. Abubakar and J. A. Valencia. 2006. Response of two wheat (Triticum estivum L.) varieties to different rates of applied NPK fertilizer. Biological and Environmental Sciences Journal for the Tropics. 3(4): 18-22. 